1 Evasion of Toll-like Receptor Recognition by Escherichia coli is mediated via

2 Population Level Regulation of Flagellin Production

3

4 Short Title: TLR5 Evasion by Uropathogenic E. coli

6 Author Names: M Lanz ${ }^{1, *}$, C Birchall ${ }^{1, *}$, L Drage $^{1, *}$, D Picton ${ }^{1, *}$, C Mowbray ${ }^{1, *}$, Q Alsenani ${ }^{1, *}$, 7 A. Tan ${ }^{1}$, A Ali ${ }^{1 \& 2}$, C Harding ${ }^{2,3}$, R Pickard ${ }^{2,3 \dagger}$, J Hall11,, PD Aldridge ${ }^{1, \S}$

8

9 Addresses:

10 1. Biosciences Institute, Newcastle University, UK

11 2. Translational and Clinical Research Institute, Newcastle University, UK

12 3. Urology Department, Freeman Hospital, Newcastle upon Tyne Hospitals NHS 13 Foundation Trust, UK

${ }^{*}$ Contributed equally

16 † Died 2018

$17 \S$ co-corresponding authors

18

19 Key words: UTI; TLR5; UPEC; Flagellin

20

21 Corresponding author for contact:

22 Phillip D Aldridge

23

phillip.aldridge@ncl.ac.uk

24 Biosciences Institute, Faculty Medical Sciences, Newcastle University, UK 


\section{Abstract (300)}

Uropathogenic Escherichia coli (UPEC) is a major cause of urinary tract infections. Analysis of the innate immune response in immortalised urothelial cells suggests that the bacterial flagellar subunit, flagellin, is key in inducing host defences. A panel of 40 clinical uroassociated Escherichia coli isolates recovered from either asymptomatic bacteruria (ASB), cystitis or pyelonephritis patients, were characterised for motility and their ability to induce an innate response in urothelial cells stably transfected with a NFKB luciferase reporter. Twenty-four isolates $(60 \%)$ were identified as motile with strains recovered from cystitis patients exhibiting a bipolar motility distribution pattern $(P<0.005)$ and associated with a 25 fold increase in NFKB signalling. Although two isolates were associated with swarm sizes of $>7 \mathrm{~cm}$ and NFKB activities of $>30$ fold $(P=0.029)$, data overall suggested bacterial motility and the NFKB signalling response were not directly correlated. To explore whether the signalling response reflected antigenic variation flagellin was purified from 11 different isolates and the urothelial cell challenges repeated. Purified flagellin filaments generated comparable ( $30.4 \pm 1.8$ to $46.1 \pm 2.5$ fold, $\mathrm{P}=\mathrm{NS}$ ) NFKB signalling responses, irrespective of either the source of the isolate or $\mathrm{H}$-serotype. These data argued against any variability between isolates being related to flagellin itself. To determine the roles, if any, of flagellar abundance in inducing these responses flagellar hook numbers of a range of cystitis and $A B U$ isolates were quantified using a plasmid encoded flagellar hook gene flgEA240C. Foci data suggested isolates were averaging between 1 and 2 flagella per cell, while only 10 to $60 \%$ each isolates population exhibited foci. These data suggested selective pressures exist in the urinary tract that allow uro-associated E. coli strains to maintain motility exploiting population heterogeneity to prevent host TLR5 recognition. 


\section{Introduction}

Urinary tract infections (UTIs) are among the most common bacterial infections suffered by individuals of all ages. They affect an estimated 150 million people worldwide including children, young adults and older populations (1). Infections are often painful and debilitating, associated with a wide range of pathogens, but the majority $(70-80 \%)$ link to the bacterial uropathogen Escherichia coli (2). Regardless of the uropathogen, treatment options remain limited with antibiotics being the first choice therapeutic. Treatment consequences, namely multi-drug resistant bacteria, often underpin persistent or rUTIs and has driven the urologic community to work collaboratively to adopt antibiotic stewardship programmes (3)

Research to date suggests UTIs link to genotypic and phenotypic variation in both the host and the uropathogen $(4,5)$. At present it is assumed that the relationship between an individual's susceptibility and bacterial virulence determines the balance between tolerance of invading pathogens and the mounting of an immune response, which in turn dictates the course of infection and subsequent recurrence (6-8). Escherichia coli reside naturally in the gastrointestinal tract, but are able to migrate from the anus, colonise the vaginal and periurethral areas, then ascend to the bladder causing asymptomatic infection (ABU) or acute cystitis (5). However, our understanding of the associated host-microbe interactions

is compounded by the observation that the same or related strains can lead to both symptomatic UTI and ABU. One outcome is that ABU patients, particularly the elderly, are often given antibiotics without justification due to clinical uncertainty (1).

While UPEC harbour a large array of virulence determinants, the ability to cause disease is dependent on the ability of the bacterium to ascend the urinary tract through adherence (fimbriae driven) and flagella-based motility (2). Moreover in vivo studies using genetically 
engineered UPEC strains and mice UTI models support flagella as being a key factor in the aetiology of an UTI (9-11). The bacterial flagellum is a macromolecular, self-assembling nano-machine whose genetics, assembly process and mechanisms of action during hostmicrobe interactions are well-documented (12-17). E. coli is known to produce 2-8 flagella per cell arranged peritrichously across the cell surface and, is characterised genetically, by approximately 60 flagellar genes organised into three loci: $f l g$, flh and fli that function to orchestrate flagellar assembly and rotation (18). Evidence supports flagellar assembly and function to be coupled to flagellar gene expression by a complex transcriptional hierarchy (19). Additionally, tight control of flagellar gene expression enables $E$. coli to efficiently passthrough ON/OFF phases of motility that can be exploited and used advantageously during host-microbe interactions (20).

In humans, uropathogens such as UPEC are sensed via TLR5 receptors, which detect flagellin: the major subunit of the flagellum filament (21). TLR5 activation results in the rapid release of urothelial host defence agents including cytokines and defensins that function individually or collectively to kill potential uropathogens $(22,23)$. However, using urine and employing in vitro chemotaxis assays Herrmann and Burman (1985) reported that only $68 \%$ (19/28) of $E$. coli isolates associated with cystitis, or an UTI, were motile (24). Yet, there is strong evidence to support uropathogenic E. coli (UPEC) exploiting flagellar-mediated movement to establish the initial ascending colonisation of the bladder from the urethra $(11,25)$. Lane et al $(2005)$ and Wright et al $(2005)$ both concluded that motility provided UPEC a competitive advantage over non-motile UPEC strains in establishing an UTI in murine models. A key challenge therefore is to understand what triggers potential uropathogenic bacteria to regulate their motility, ascend the urethra and infect the bladder. 
102 Using clinically derived uro-associated $E$. coli isolates data are presented suggesting a 103 regulatory mechanism linked to population heterogeneity that maintains motility within a 104 bacterial population, but at levels below a threshold required for innate immune recognition. 105 


\section{Results}

Uro-associated E. coli motility and the urothelial innate response.

Forty uro-associated E. coli isolates were curated from patients presenting with either

cystitis, pyelonephritis, asymptomatic bacteriuria (ABU) or UTI-associated bacteraemia.

Semi-quantitative agar assays measuring the size of a bacterial swarm after $8 \mathrm{hrs}$ (Figure

1A) were used to assess motility of these isolates and $24(60 \%)$ were identified as motile

(Fig 1A \& B, Table S1). In general, the swarms of isolates recovered from ABU patients

measured between 0.8 and $5.4 \mathrm{~cm}$, while cystitis strains exhibited a bipolar motility distribution pattern with strains swarming less $(n=6)$ or greater $(n=4)$ than $5.4 \mathrm{~cm}$ respectively (Fig 1B; $\mathrm{P}<0.005$ ).

The impact of bacterial motility on the urothelial innate response was assessed in vitro using heat-killed isolates $\left(1 \times 10^{5} \mathrm{CFU} / \mathrm{ml}\right)$ and bladder RT4 cells stably transfected with a NFKB luciferase reporter (26). Following these challenges $33(83 \%)$ of all the isolates were associated with a 2-5 fold increase in NFKB signalling (Fig 1B \& C), with 7 of the motile isolates associated with increases of $>5$-fold. Two isolates recovered from cystitis patients were associated with NFKB activities of $>30$ fold (Fig 1C; $P=0.029)$ and swarm sizes of $>7$ $\mathrm{cm}$ (Fig 1B). These data suggested that bacterial motility linked to a NFKB signalling response, but that the two were not directly correlated.

Urothelial responses to flagellins prepared from uro-associated E. coli isolates

UTIs are ascending infections and urothelial cells respond to potential uropathogens via 131 flagellin detection, TLR5 signalling and the release of antimicrobial killing and pro- 
132 inflammatory agents (26). TLR5 proteins recognise a conserved motif found in the majority 133 of flagellins (27), which in E. coli is referred to as the $\mathrm{H}$-antigen with to date 53 flagellin or $134 \mathrm{H}$-serotypes being identified (28) (Table S1). To explore whether the signalling response reflected antigenic variation flagellin was purified from 11 different uro-associated E. coli isolates (Table S1: Lab IDs PYL3398-PYL3424) and the urothelial cell challenges repeated 137 (Fig 2A). Purified flagellin filaments generated robust and comparable (30.4 \pm 1.8 to $46.1 \pm 2.5$ 138 fold, $P=N S)$ NFKB signalling responses, irrespective of either the source of the isolate or $\mathrm{H}$-serotype. These data argued against any variability between isolates being related to flagellin itself.

TLR-signalling activates a complex signalling cascade that leads to the degradation of $1 \mathrm{kB} \alpha$ and NFKB release that activates gene expression (29). Smith et al (2003) using transfected Chinese hamster ovary cells, showed TLR5 recognition of flagellin to be dose-dependent (30). A dose-dependent response to flagellin, measured through IKBa protein levels and NFKB induction was also observed in RT4 urothelial cells (Fig 2B and C). Interestingly, using purified flagelllin from E. coli UTI3408 experiments suggested a peak response at approximately $2.5 \mathrm{ng} / \mathrm{ml}$.

Urothelial responses to outer membranes prepared from uro-associated E. coli isolates

Data from in vitro and in vivo studies, both murine and clinical, suggest TLR4 signalling as well as TLR5 impacts UTI host-microbe interactions (21,31-33). TLR4 recognises 154 lipopolysaccharide, the major outer membrane (OM) component of Gram-negative bacterial species such as UPEC (34). Therefore, the potential roles of TLR4 and LPS were explored to help explain the differing NFKB signalling responses observed during whole bacterial cell challenges. Outer membrane preparations of four clinical isolates (3 motile [PYL3398, 
158

UTI3408 and UTI3412] (Table S1) and 1 non-motile [ABU3416]) and two control strains NCTC10418 and CFT073, were used to challenge RT4 $\left(T_{L}{ }^{+}\right)$cells and RT4 cells where either TLR4 or TLR5 expression had been inhibited by siRNA knockdown (Fig 2D). The innate response was determined through measurement of the pro-inflammatory cytokine IL8. Data presented in Fig 2D showed that the IL-8 responses to flagellin $(50 \mathrm{ng} / \mathrm{ml})$ and whole bacterial cell challenges were significantly reduced in the TLR5 $5^{\text {siRNA }}$ cells $(P=0.0013)$. While a two-fold reduction in IL8 was observed in the NCTC14028 challenged TLR4 ${ }^{\text {siRNA }}$ cells. This decrease was not significant and not mirrored in either the flagellin or CFT073 challenges. Challenges with OM sample preparations supported reduced IL-8 concentrations overall, but again a significant reduction was detected only in the TLR5 silenced cells (Fig 2D P $<0.001$ ). While these data suggested the OM preparations maybe contaminated with flagellin they also supported minor roles for LPS and TLR4 in the RT4 bladder cell innate response to an acute infection.

Correlating urothelial responses to flagellar abundance amongst uro-associated E. coli isolates

Data in Fig 1 and 2 indicated that flagellin isolated from a range of uro-associated $E$. coli induced an innate response as shown by NFKB signalling and effector (IL-8) responses. To determine the roles, if any, of flagellar abundance in inducing these responses flagellar hook numbers of cystitis (5), ABU (10) and PYL (1) isolates were quantified (Fig 3A) using the plasmid encoded flagellar hook gene flgEA240C (20). The control E. coli strain NCTC10418 averaged 2.5 foci per cell, while foci data suggested the clinical isolates and CFT073 were averaging between 1 and 2 flagella per cell $(P=0.148)$ (Fig $3 B, x$-axis). 
183 However, only 10 to $60 \%$ of the CFT073 and clinical isolate cell populations exhibited 184 FlgEA240C foci compared to $80 \%$ of the NCTC10418 cell population (Fig 3B, y-axis). Moreover, using NCTC10418 as the control and exploiting IL-8 concentrations resulting from RT4 urothelial cells challenge experiments, identified a link between flagellar numbers and 187 the host response (Fig $3 C \mathrm{P}=0.013$ ). These data suggested selective pressures exist in 188 the urinary tract that allow uro-associated E. coli strains to maintain motility but exploit 189 population heterogeneity to prevent host TLR5 recognition and bacterial killing.

191 The flagellar system is regulated at the expression level by a transcriptional hierarchy 192 controlled by the master transcriptional regulatory $\mathrm{FlhD}_{4} \mathrm{C}_{2}(35)$. $\mathrm{FlhD}_{4} \mathrm{C}_{2}$ levels are sensitive 193 to a wide range of regulatory mechanisms that include transcription, translation and protein 194 stability (36-39). Population data (Fig 3B) suggested that the number of flagella observed 195 linked to reduced flagellar gene expression. To examine this further a high copy number 196 plasmid encoding fIhDC was transformed into the control strain NCTC10418 and UTI3408 197 (25\% Fla+; $1.66 \mathrm{Fla} /$ cell; 0.19 relative IL-8 production: Table S1). RT4 urothelial cell 198 challenge experiments performed using these transformed strains showed that increasing 199 fIhDC expression supported a two-fold increase in IL-8 concentrations for UTI3408 200 compared to no change for NCTC10418 (Fig 3D). 


\section{Discussion}

204 Motility is a well-recognised pathogenicity, virulence and/or colonisation factor for a wide

range of bacterial species including uropathogenic E. coli (UPEC) (40). However, motility links to flagellin production, which is the bacterial ligand for the mammalian host receptor TLR5. TLR5 activation releases host bacterial killing agents including cytokines and antimicrobial agents that facilitate bacterial killing, and clearance from potential colonisation and/or infection sites $(21,26,30)$. Data from this study exploiting clinical isolates associated with UTIs suggest that uro-associated E. coli exploit population heterogeneity to maintain motility, but prevent the TLR5-dependent activation of the host innate immune response (41). Essentially these bacterial populations manipulate their flagellar production so they can survive and/or colonise the urinary tract, but remain under the host radar. It has been

214 reported that $E$. coli swims efficiently with only one flagellum per cell (42) and using a FlgEA240C foci labelling approach uro-associated clinical isolates and the UPEC model strain CFT073 cultured in vitro were characterised by 1 to 2 flagella per cell (Fig 3). Together these data support E. coli motility and survivability within the lower urinary tract environment. However, once motility is enhanced through increased flagellar production, modelled in vitro using strain 3408 (Fig 3D), these microbes become visible to urothelial cell TLRs. Detection is associated with the release of a plethora of host defence molecules, shown here in these

Flagellar systems have been shown to be subject to multiple regulatory controls (43). For example, Salmonella enterica generates a bipolar $\mathrm{Fla}^{-} / \mathrm{Fla}^{+}$population in response to either nutritional and/or cell envelope stresses (44) while Caulobacter crescentus divides asymmetrically to produce one motile cell each division, ensuring a subpopulation of motile 
228 growth, it is well recognised to be nutritionally weak when compared to normal laboratory

229 growth conditions (46). Therefore, it could be argued that uro-associated E. coli completely

230 switching off flagellin synthesis to evade TLR5 recognition and the host immune response

231 is not compatible with its survival. However, exploiting population heterogeneity to regulate

232 environmental flagellin concentrations ensures microbial survivability and potentially host

233 colonisation. Additionally, the concept that immune evasion i.e. host TLR5 recognition of

234 flagellin proteins drives uro-associated E. coli to downregulate flagellar production may help

235 unravel the pathogenesis of asymptomatic bacteria, defined as the presence of bacteria in

236 the urinary tract without inflammatory symptoms.

238 It was interesting, however, that following in vitro culture the motility and NFผB observations

239 (Fig 2B) did not differentiate between the ASB and cystitis strains. During active UTIs in

240 humans it has been reported that infecting bacteria need to divide rapidly to survive the host

241 innate response. Doubling times have been estimated to be between 17 to 34 minutes and

242 averaging 22 minutes (47). This rapid growth response characterised by upregulation of

243 UPEC translational machinery results in high cell densities that are orchestrated to both

244 overwhelm and escape the host defences (48). The latter is supported by growth

245 experiments using steady state chemostat cultures where faster growing E. coli produce

246 more flagella (Sim 2017).

248 However, a key question relates to the cues in the urogenital tract that trigger increased 249 growth and UPEC infections. It is generally accepted that low nutrient conditions up-regulate 250 E. coli flagellar synthesis via activation of the flhDC operon (49) although other signals 251 including urine osmolality and $\mathrm{pH}$ cannot be ignored (50). Studies in Salmonella grown in 252 low nutrient conditions have shown that non flagellar regulators such as RfIP, a regulator 253 that modulates ClpXP recognition of $\mathrm{FlhD}_{4} \mathrm{C}_{2}$, can impact the master regulator $\mathrm{FIhD}_{4} \mathrm{C}_{2}$ 
254 activity and hence flagellin synthesis $(39,44,49,51)$. Whether comparable regulators function

255 to trigger flagellar growth in uro-associated E.coli is not known although NarL, ModE, Metj,

256 GadE and YdeO, all sensors of environmental cues, have been identified as playing

257 potential roles in infection-specific UPEC gene expression (48).

259 Population heterogeneity is not an original concept and has been shown to be exploited by 260 a number of bacterial species to retain a selective advantage particularly during growth in 261 specific environmental niches $(41,52,53)$. However, its exploitation by uro-associated $E$. coli 262 to regulate flagellin synthesis and avoid the host defences is novel. This study was not 263 designed to identify the regulatory mechanisms functioning to control flagellin synthesis in 264 the urogenital tract, but environmental and genetic cues including population densities, urine 265 osmolality and electrolytes, urinary and bacterial metabolites, and $\mathrm{pH}$ need to be 266 investigated further. 


\section{Materials and Methods}

\section{Strains and General Microbiology}

E. coli strains used in the study have either been previously described (26). Strains PYL3398 to $\mathrm{ABU} 3710$ were a kind donation from the Diagnostic Microbiology Unit at the Freeman hospital, Newcastle NHS Trust, Newcastle upon Tyne between 2010 and 2012 (Table S1 and S2). No ethics were necessary for the use of these strains as the researchers did not have access to clinical records and the only information provided by the unit was the type of UTI associated with each isolate. Strains ABU4738-ABU4745 came from the clinical study of Drage et al (2019) that was conducted under ethically approved study protocols (ref: REC14-NE-0026).

Strains used during this study were propagated in or on Luria-Bertani (LB) medium using $1.5 \%$ agar for plates. Incubation, unless stated otherwise, was overnight at $37^{\circ} \mathrm{C}$ with liquid cultures aerated by orbital shaking at $160 \mathrm{rpm}$. All motility assays were performed by either direct inoculation using a toothpick or inoculating $3 \mu \mathrm{l}$ of an overnight culture onto motility agar ( $1 \%$ Tryptone, $0.5 \% \mathrm{NaCl}, 0.3 \%$ Agar) and incubating for 8 hours at $30^{\circ} \mathrm{C}$. Images of motility swarms were digitally captured, and the vertical and horizontal diameter measured to generate an average swarm distance using ImageJ. All swarm assays were performed with a minimum of three independent colonies. Transformation of the plasmids pflhDC or pBADflgEA240C were performed by electroporation as described previously (20). Selection 290 for plasmids was performed using either $100 \mu \mathrm{g} / \mathrm{ml}$ Ampicillin or $50 \mu \mathrm{g} / \mathrm{ml}$ Kanamycin. 291 pflhDC was generated by cloning a PCR product using the primers flhD-42FBam 


\section{3}

[ggcggatccCGCTGCTGGAGTGTTTGTCC] into the high copy number vector pSE280 using standard cloning techniques.

\section{Isolation of Flagellin and Outer membranes}

All flagellin and outer membrane $(\mathrm{OM})$ preparations were based on $1 \mathrm{~L}$ cultures of strains grown to an $\mathrm{OD}_{600}$ of $0.6-0.7$. Cells were centrifuged at $3890 \mathrm{~g}$ and cell pellets resuspended in cold 10mM HEPES pH 7.4. For flagellin isolation, cell suspensions were sheared using an Ultra-Turrax blending stick for 2 minutes set at $13500 \mathrm{rpm}$. The same protocol was used prior to $\mathrm{OM}$ isolation to reduce flagellin contamination. Blended supernatants were centrifuged at $100,000 \mathrm{~g}$ for 1 hour at $4^{\circ} \mathrm{C}$ to collect sheared flagellar filaments. The pellets were washed by repeating this procedure three times. Pellets were resuspended in $10 \mathrm{mM}$ HEPES pH 7.4 and centrifuged at $3890 \mathrm{~g}$ to improve the removal of cell debris between each ultra-centrifuge wash step. The washed flagellin pellets were resuspended in $500 \mu \mathrm{l}$ 10mM HEPES $\mathrm{pH} 7.4$ and stored at $-20^{\circ} \mathrm{C}$.

For outer membrane isolation cell suspensions were lysed using a Constant Systems cell disruptor at 23kPSI. Lysed cell suspensions were centrifuged at $12000 \mathrm{~g}$ at $4^{\circ} \mathrm{C}$ for 40 minutes, the supernatant layered onto a sucrose gradient and centrifuged at $56000 \mathrm{~g}$ for 36 hours at $4^{\circ} \mathrm{C}$. Outer membrane fractions were resuspended and washed once in $10 \mathrm{mM}$ HEPES pH7.4. The washed outer membrane fraction was collected by centrifuging at $134000 \mathrm{~g}$ for 6 hours at $4^{\circ} \mathrm{C}$ and the resulting pellet resuspended in $500 \mu \mathrm{l} 10 \mathrm{mmM}$ HEPES. The quality of preparations was assessed using standard SDS polyacrylamide gel electrophoresis.

NFKB reporter assay, IL-8 ELISA and Immunoblots 
318 Growth conditions for the bladder RT4 cell line has been previously described (26). All 319 challenges were performed using 24 well plates seeded with 500,000 cells in $500 \mu \mathrm{l}$, and 320 the cells grown until 80-90\% confluent. Bladder RT4 cells were challenged in triplicate with 321 either isolated outer membrane preparations (100 ng/ml protein content), flagellin (0-250 $322 \mathrm{ng} / \mathrm{ml}$ ) or heat-killed whole cells at $37^{\circ} \mathrm{C}$ and $5 \% \mathrm{CO}_{2}(26)$. Challenges were stopped after 32324 hours, the extracellular media collected and stored at $-20^{\circ} \mathrm{C}$. Interleukin 8 concentrations $324(\mathrm{pg} / \mathrm{ml})$ were assayed using an eBioscience IL-8 ELISA kit following the manufacturer's instructions. Measurement of RT4 NFKB reporter activity was as previously described (26). For IKBa immunoblots, challenged RT4 cells were lysed in RIPA Buffer collected, quantified using a Micro BCA protein assay kit (Thermo) and either stored at $-20^{\circ} \mathrm{C}$ or $10 \mu \mathrm{g}$ used for immunoblots with an Anti-lkBa antibody (New England Biolabs) (54).

Inhibition of TLR4 and TLR5 SiRNA expression

TLR4 and TLR5 knockdown experiments using RT4 cells and siRNA were performed as described previously (55). siRNAs used were as follows: s14196 (TLR4) and s14199 (TLR5) and AM4611 (negative siRNA \#1) as a control. All challenges were performed as described previously and media bathing the cells analysed using an eBioscience IL-8 ELISA kit following the manufacturer's instructions.

\section{Quantification of Flagellar abundance}

339 Expression of $f \mathrm{gEA} 240 \mathrm{C}$ was analysed following bacterial growth at $37^{\circ} \mathrm{C}$ in $\mathrm{LB}$ media containing $0.1 \%$ arabinose with shaking until an OD600 of 0.6 to 0.7 . Staining of the cells was performed using AlexaFluor 568 (20). Essentially, bacterial cell suspensions were immobilised on a $1 \%$ agarose padded microscope slide and samples analysed in triplicate at 100x objective using a Nikon Eclipse Ti inverted microscope capturing both phase 
344 contrast (100 ms exposure) and red channel images (1000 ms exposure) at five different

345 fields of view. Five randomly chosen fields were analysed manually using the ImageJ cell

346 counter plugin generating data where $n=200-300$ cells. Foci per cell was averaged across

347 the five fields of view to enumerate the level of cell flagellation, as well as the distribution of

348 flagella over the population.

349

350 Data Analysis and Presentation

351 Data and statistical analysis were performed using MS Excel including the use of ANOVA. 352 Images for figure panels were processed and cropped using ImageJ and imported into 353 Adobe illustrator for formatting. All figures were collated in Adobe illustrator to achieve the 354 correct resolution. 
bioRxiv preprint doi: https://doi.org/10.1101/2021.11.18.469103; this version posted November 23, 2021. The copyright holder for this preprint (which was not certified by peer review) is the author/funder, who has granted bioRxiv a license to display the preprint in perpetuity. It is made available under aCC-BY 4.0 International license.

\section{6}

357

358

359

371 financial support in the form of bridge funding for C.M.

\section{Conflict of Interests}

374 The authors declare that there are no conflicts of interest. 
Figures and Legends

A.

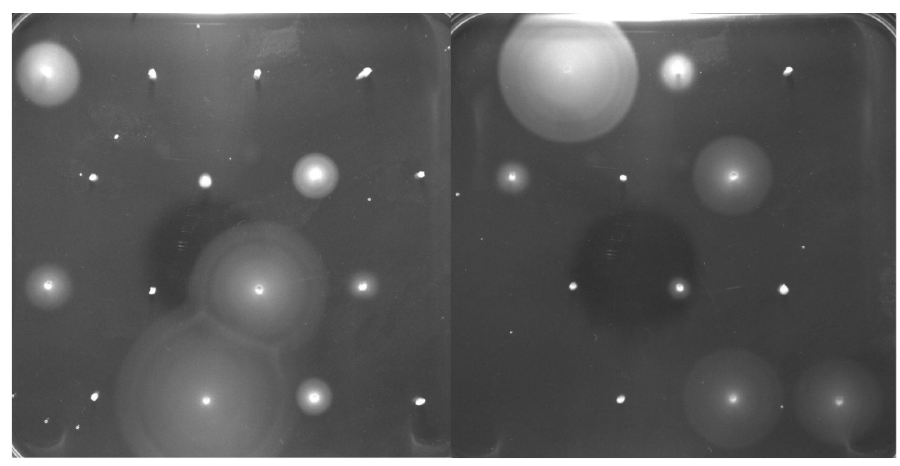

B.

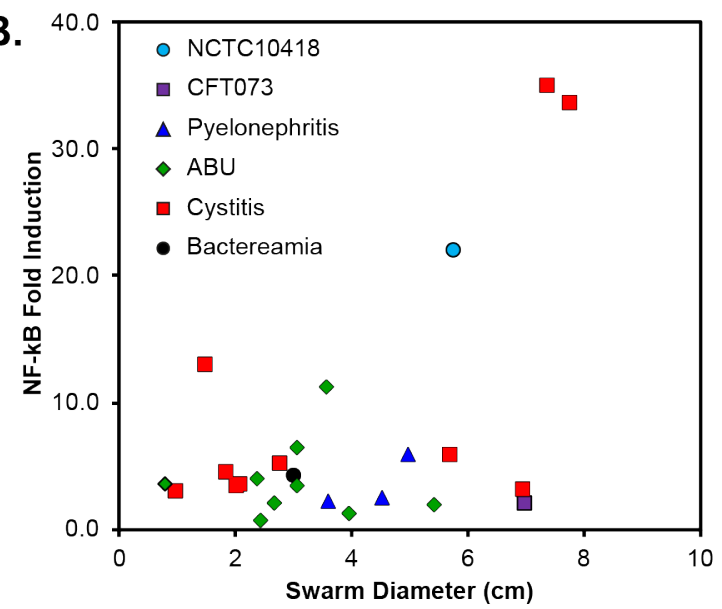

C.

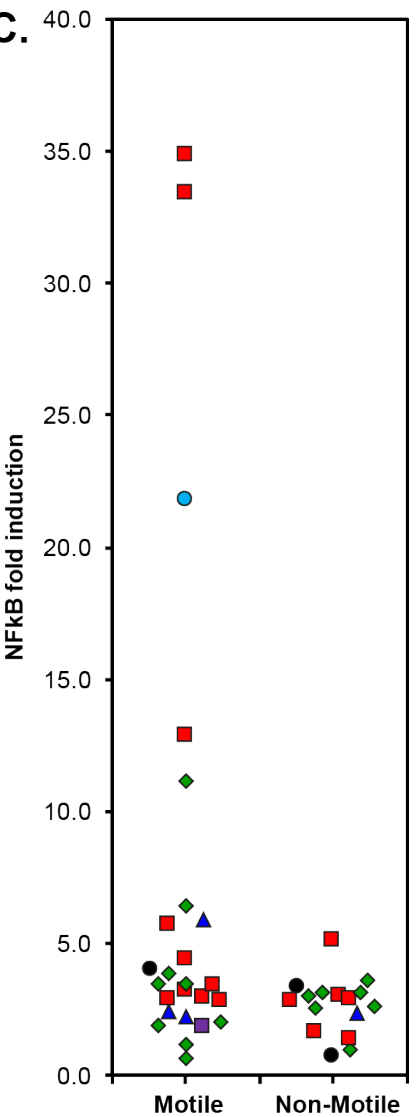

379 Figure 1: Motility of clinical uro-associated isolates and RT4 bladder cell NF-kB signalling. A) Motility agar assay data of a selection of clinical UPEC isolates (Table S1 and S2) showing the diverse range of phenotypes. B) Quantification of swarm diameter for $n=3$ independent colonies of each clinical isolate plotted against NFKB induction. Control strains, NCTC10418 and CFT073, and clinical isolates are colour coded. C) NFKB fold induction of all motile and non-motile UPEC clinical isolates. Points have been scattered left or right with respect to the $\mathrm{x}$-axis for clarity. 
A.

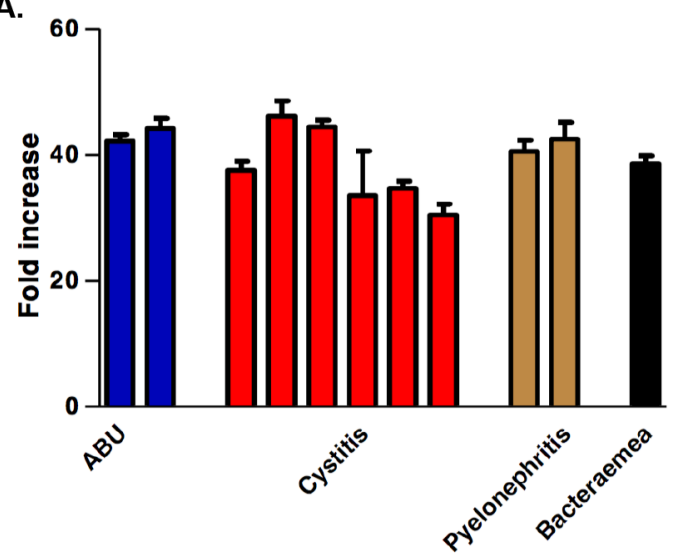

C.

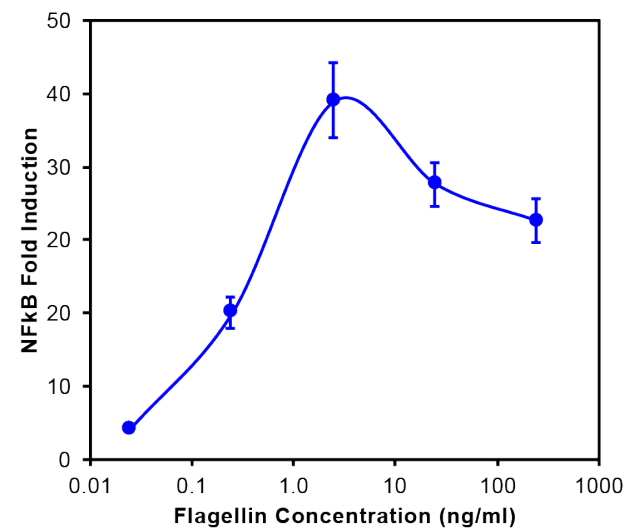

B. Flagellin Concentration (ng/ml)

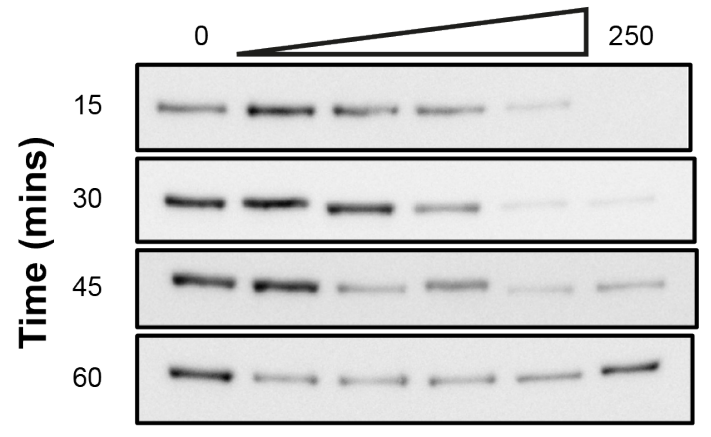

D.

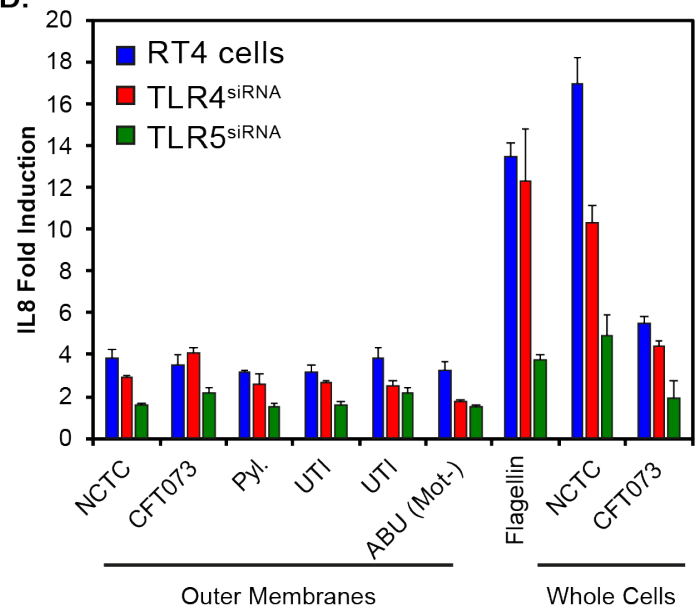

Figure 2: NF-KB and IL-8 responses of bladder RT4 cells challenged with flagellin, bacterial outer membrane preparations and whole cells. A) NF- $\kappa B$ response of RT4 bladder cells challenged for 24 hours with flagellin filaments $(250 \mathrm{ng} / \mathrm{ml})$ isolated from 11 different uro-associated E. coli (strains PYL3398-PYL3324: Table S1). B) Immunoblot analysis of $\mathrm{IKBa}$ following dose dependent challenges of RT4 cells with flagellin filaments isolated UTI3408. C) Quantification of NFKB induction following dose dependent challenges of RT4 cells with flagellin filaments isolated from UTI3408. Data shown is the average of two technical repeats and 3 independent challenges. D) IL-8 concentrations of RT4 cell media following transfection with siRNAs targeting either TLR4 or TLR5 expression and challenging for 24 hours with either outer membrane preparations, flagella filaments (50 $\mathrm{ng} / \mathrm{ml}$ ) or heat killed whole bacteria. 
A.
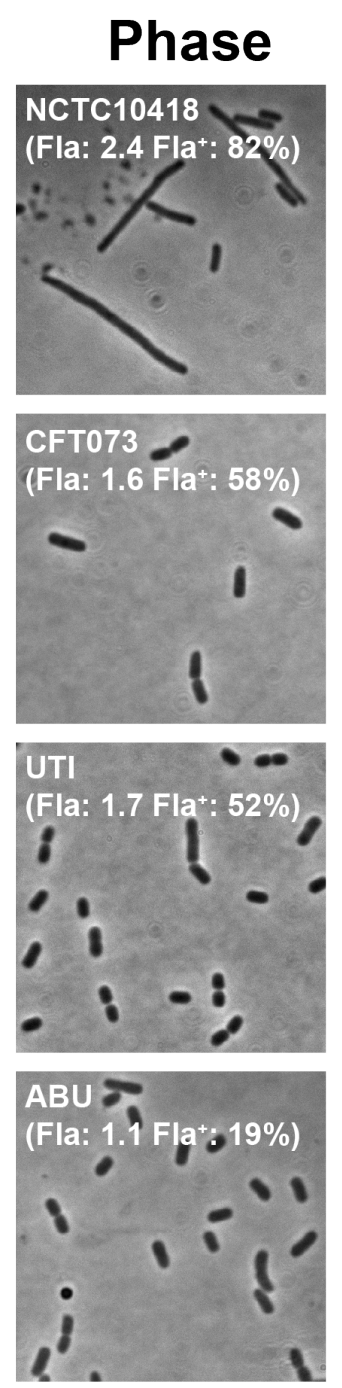
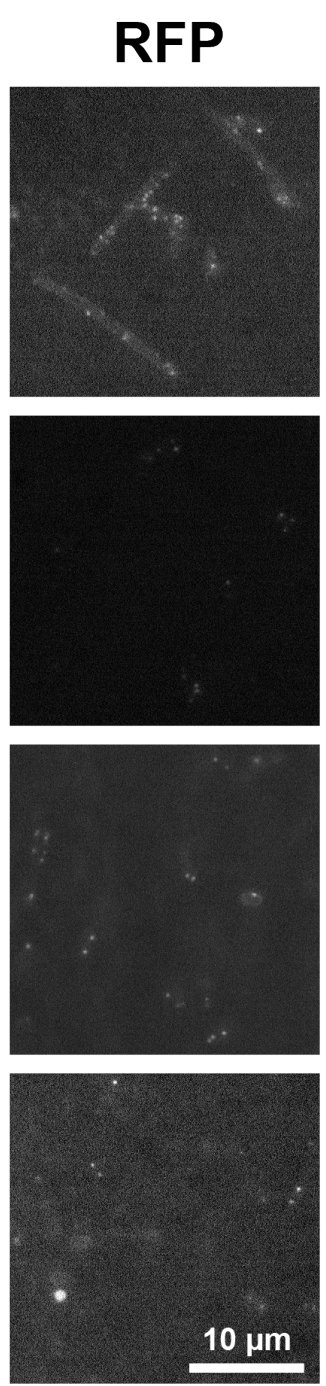
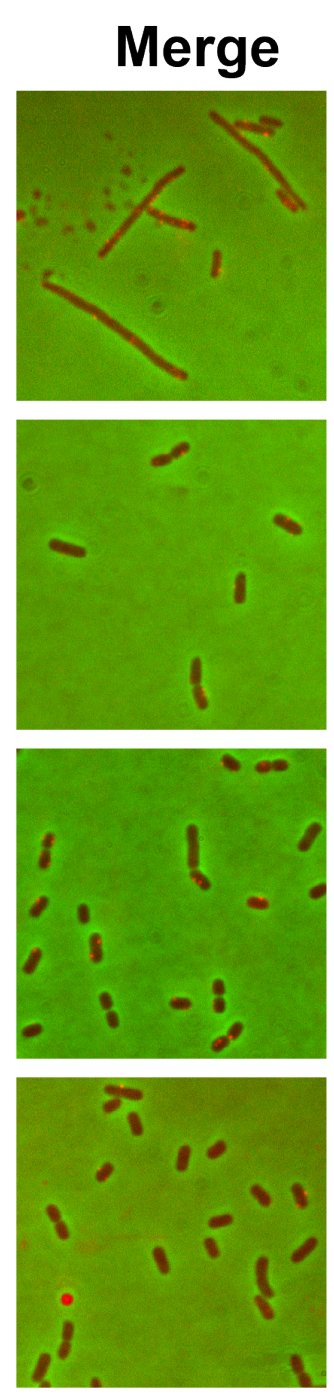

Figure 3: Uro-associated E. coli population heterogeneity and UPEC evasion of the TLR5 response. A) Phase contrast and fluorescent images of FlgEA240C foci in the control strains NCTC10418 and CFT073, and two uro-associated clinical isolates. Quantification of a minimum of 250 cells per strain is shown in brackets where Fla: = average number of FlgE foci per cell and Fla+: = percentage of the population with foci. Images are chosen to show foci and may not reflect quantified numbers. B) Scatter plot showing average foci per cell versus flagellated population. The range of average foci per cell for all strains except NCTC10418 are within experimental error $(P=0.143)$. C) Scatter plot showing percentage of flagellated population versus relative NFKB induction (control strain NCTC10418 $=1.0$ ). D) IL-8 production, presented as a ratio, following challenges of RT4 cells with NCTC10418 ( $\mathrm{p} f / h D C$-ve) or UTI3408 ( $\mathrm{pflhDC}$ transformed). 
416 Table S1: Motile Strains and associated data used in this study

\begin{tabular}{|c|c|c|c|c|c|c|}
\hline \multirow{2}{*}{$\begin{array}{c}\text { Lab } \\
\text { Strain ID }\end{array}$} & \multirow[b]{2}{*}{ Source* } & \multirow{2}{*}{$\begin{array}{l}\text { Flagellin } \\
\text { Serotype }\end{array}$} & \multirow{2}{*}{$\begin{array}{c}\text { Average } \\
\text { swarm } \\
\text { diameter }(\mathbf{c m})\end{array}$} & \multicolumn{2}{|c|}{$\begin{array}{c}\text { Flagellar } \\
\text { abundance } \S\end{array}$} & \multirow[b]{2}{*}{ Reference } \\
\hline & & & & $\begin{array}{l}\text { Avg } \\
\text { Fla I } \\
\text { cell }\end{array}$ & $\% \mathrm{Fla}^{+}$ & \\
\hline \multicolumn{7}{|c|}{ Strains used in Figure 1, 2 and 3} \\
\hline 2743 & NCTC10418 & & 5.78 & 2.35 & 82 & (26) \\
\hline 3373 & CFT073 & $\mathrm{H} 1$ & 7.02 & 1.59 & 58 & $(56)$ \\
\hline 3398 & PYL & $\mathrm{H} 1$ & 3.59 & 1.46 & 7 & \multirow{24}{*}{ This study } \\
\hline 3406 & $A B U$ & $\mathrm{H} 18$ & 3.06 & & & \\
\hline 3408 & UTI & $\mathrm{H} 1$ & 5.71 & 1.66 & 25 & \\
\hline 3409 & UTI & H5 & 1.87 & & & \\
\hline 3411 & UTI & $\mathrm{H} 6$ & 7.78 & & & \\
\hline 3412 & UTI & $\mathrm{H} 18$ & 1.49 & 1.36 & 27 & \\
\hline 3414 & UTI & & 7.39 & & & \\
\hline 3415 & BAC & H5 & 3.04 & & & \\
\hline 3417 & UTI & $\mathrm{H} 1$ & 2.05 & & & \\
\hline 3419 & $A B U$ & $\mathrm{H} 6$ & 3.56 & & & \\
\hline 3424 & PYL & $\mathrm{H} 18$ & 4.98 & & & \\
\hline 3425 & PYL & $\mathrm{H} 1$ & 4.51 & & & \\
\hline 3692 & $A B U$ & & 3.07 & & & \\
\hline 3693 & $A B U$ & & 2.67 & 1.24 & 8 & \\
\hline 3694 & $A B U$ & & 5.41 & & & \\
\hline 3695 & $A B U$ & & 3.96 & 1.41 & 10 & \\
\hline 3697 & $A B U$ & & 2.44 & 1.60 & 6 & \\
\hline 3698 & $\mathrm{ABU}$ & & 2.36 & & & \\
\hline 3699 & $A B U$ & $\mathrm{H} 4$ & 0.77 & & & \\
\hline 3701 & UTI & $\mathrm{H} 27$ & 2.80 & 1.68 & 52 & \\
\hline 3702 & UTI & $\mathrm{H} 4$ & 6.97 & 1.52 & 24 & \\
\hline 3703 & UTI & & 1.00 & 1.71 & 10 & \\
\hline 3704 & UTI & & 2.10 & & & \\
\hline 3710 & $A B U$ & $\mathrm{H} 4$ & 2.85 & & & \\
\hline \multicolumn{7}{|c|}{ Additional strains used in Figure 3} \\
\hline 4738 & $A B U$ & $\mathrm{H} 5$ & 1.58 & 1.67 & 50 & \multirow{8}{*}{ (8) } \\
\hline 4739 & $A B U$ & $\mathrm{H} 1$ & 2.41 & 1.62 & 35 & \\
\hline 4740 & $A B U$ & $\mathrm{H} 1$ & 2.25 & 1.44 & 57 & \\
\hline 4741 & $A B U$ & $\mathrm{H} 18$ & 2.10 & 1.81 & 11 & \\
\hline 4742 & $A B U$ & H18 & 2.25 & 1.14 & 19 & \\
\hline 4743 & $A B U$ & $\mathrm{H} 5$ & 3.67 & 1.62 & 36 & \\
\hline 4744 & $A B U$ & $\mathrm{H} 18$ & 1.67 & 1.45 & 46 & \\
\hline 4745 & $A B U$ & $\mathrm{H} 6$ & 2.00 & 1.14 & 7 & \\
\hline
\end{tabular}

417 § Data shown to indicate the strains used in Figure 3

418 *PYL: Pyelonephritis; ABU: asymptomatic bacteriuria; UTI: Acute cystitis; BAC:

419 Bacteraemia 
Table S2 Non-motile strains used in Figures 1 and 2D.

421

\begin{tabular}{|c|c|}
\hline $\begin{array}{c}\text { Lab } \\
\text { Strain ID }\end{array}$ & Source $^{*}$ \\
\hline 3399 & ABU \\
\hline 3400 & ABU \\
\hline 3401 & UTI \\
\hline 3402 & BAC \\
\hline 3403 & UTI \\
\hline 3407 & UTI \\
\hline 3410 & BAC \\
\hline 3413 & ABU \\
\hline 3416 & ABU \\
\hline 3418 & ABU \\
\hline 3420 & ABU \\
\hline 3422 & PYL \\
\hline 3696 & ABU \\
\hline 3701 & UTI \\
\hline 3706 & UTI \\
\hline 3707 & UTI \\
\hline *See Table S1 descriptors
\end{tabular}




\section{References}

1. Foxman B. Epidemiology of urinary tract infections: incidence, morbidity, and economic costs. Am J Med. 2002 Jul 8;113 Suppl 1A:5S-13S.

2. Klein RD, Hultgren SJ. Urinary tract infections: microbial pathogenesis, hostpathogen interactions and new treatment strategies. Nat Rev Micro. Springer US; 2020 Feb 18;18:211-26.

3. Fisher H, Oluboyede $\mathrm{Y}$, Chadwick T, Abdel-Fattah M, Brennand C, Fader M, et al. Continuous low-dose antibiotic prophylaxis for adults with repeated urinary tract infections (AnTIC): a randomised, open-label trial. Lancet Infect Dis. 2018 Sep;18(9):957-68.

4. Hawn TR, Scholes D, Wang H, Li SS, Stapleton AE, Janer M, et al. Genetic variation of the human urinary tract innate immune response and asymptomatic bacteriuria in women. PLoS ONE. Public Library of Science; 2009;4(12):e8300.

5. Schreiber HL, Conover MS, Chou W-C, Hibbing ME, Manson AL, Dodson KW, et al. Bacterial virulence phenotypes of Escherichia coli and host susceptibility determine risk for urinary tract infections. Science Translational Medicine. American Association for the Advancement of Science; 2017 Mar 22;9(382):eaaf1283.

6. Chan CY, John ALS, Abraham SN. Mast Cell Interleukin-10 Drives Localized Tolerance in Chronic Bladder Infection. Immunity. Elsevier Inc; 2013 Feb 21;38(2):349-59.

7. Choi HW, Bowen SE, Miao Y, Chan CY, Miao EA, Abrink M, et al. Loss of Bladder Epithelium Induced by Cytolytic Mast Cell Granules. Immunity. 2016 Dec;45(6):1258-69.

8. Drage LKL, Robson W, Mowbray C, Ali A, Perry JD, Walton KE, et al. Elevated urine IL-10 concentrations associate with Escherichia coli persistence in older patients susceptible to recurrent urinary tract infections. Immun Ageing. Immunity \& Ageing; 2019 Jul 10;16:1-11.

9. Lane MC, Alteri CJ, Smith SN, Mobley HLT. Expression of flagella is coincident with uropathogenic Escherichia coli ascension to the upper urinary tract. Proc Natl Acad Sci USA. 2007 Oct 16;104(42):16669-74.

10. Lane MC, Lockatell V, Monterosso G, Lamphier D, Weinert J, Hebel JR, et al. Role of motility in the colonization of uropathogenic Escherichia coli in the urinary tract. Infect Immun. 2005 Nov;73(11):7644-56.

11. Wright KJ, Seed PC, Hultgren SJ. Uropathogenic Escherichia coli flagella aid in efficient urinary tract colonization. Infect Immun. 2005 Nov;73(11):7657-68.

12. Chevance FFV, Hughes KT. Coordinating assembly of a bacterial macromolecular machine. Nat Rev Micro. 2008 Jun;6(6):455-65.

13. Minamino T, Imada K. The bacterial flagellar motor and its structural diversity. Trends Microbiol. 2015 May;23(5):267-74. 
bioRxiv preprint doi: https://doi.org/10.1101/2021.11.18.469103; this version posted November 23, 2021. The copyright holder for this preprint (which was not certified by peer review) is the author/funder, who has granted bioRxiv a license to display the preprint in perpetuity. It is made available under aCC-BY 4.0 International license.

463

14. Minamino T. Protein export through the bacterial flagellar type III export pathway. Biochim Biophys Acta. 2014 Aug;1843(8):1642-8.

15. Porter SL, Wadhams GH, Armitage JP. Signal processing in complex chemotaxis pathways. Nat Rev Micro. Nature Publishing Group; 2011 Feb 1;9(3):153-65.

16. Smith TG, Hoover TR. Deciphering bacterial flagellar gene regulatory networks in the genomic era. Adv Appl Microbiol. 2009;67:257-95.

17. Snyder LAS, Loman NJ, Fütterer K, Pallen MJ. Bacterial flagellar diversity and evolution: seek simplicity and distrust it? Trends Microbiol. 2009 Jan;17(1):1-5.

18. Aldridge P, Hughes KT. Regulation of flagellar assembly. Curr Opin Microbiol. 2002 Apr;5(2):160-5.

19. Chilcott GS, Hughes KT. Coupling of flagellar gene expression to flagellar assembly in Salmonella enterica serovar Typhimurium and Escherichia coli. Microbiol Mol Biol Rev. 2000 Dec;64(4):694-708.

20. Sim M, Koirala S, Picton D, Strahl H, Hoskisson PA, Rao CV, et al. Growth rate control of flagellar assembly in Escherichia coli strain RP437. Sci Rep. 2017 Jan $24 ; 7: 41189$.

21. Andersen-Nissen E, Hawn TR, Smith KD, Nachman A, Lampano AE, Uematsu S, et al. Cutting edge: Tlr5-/- mice are more susceptible to Escherichia coli urinary tract infection. J Immunol. 2007 Apr 15;178(8):4717-20.

22. Ali ASM, Townes CL, Hall J, Pickard RS. Maintaining a sterile urinary tract: the role of antimicrobial peptides. J Urol. 2009 Jul;182(1):21-8.

23. Sivick KE, Mobley HLT. Waging war against uropathogenic Escherichia coli: winning back the urinary tract. Infect Immun. 2010 Feb;78(2):568-85.

24. Herrmann B, Burman LG. Pathogenesis of Escherichia coli cystitis and pyelonephritis: apparent lack of significance of bacterial motility and chemotaxis towards human urine. Infection. 1985 Jan;13(1):4-7.

25. Schaeffer AJ, Schwan WR, Hultgren SJ, Duncan JL. Relationship of type 1 pilus expression in Escherichia coli to ascending urinary tract infections in mice. Infect Immun. American Society for Microbiology (ASM); 1987 Feb;55(2):373-80.

26. Ali ASM, Mowbray C, Lanz M, Stanton A, Bowen S, Varley CL, et al. Targeting Deficiencies in the TLR5 Mediated Vaginal Response to Treat Female Recurrent Urinary Tract Infection. Sci Rep. Nature Publishing Group; 2017 Sep 8;7(1):11039.

27. Andersen-Nissen E, Smith KD, Strobe KL, Barrett SLR, Cookson BT, Logan SM, et al. Evasion of Toll-like receptor 5 by flagellated bacteria. Proc Natl Acad Sci USA. 2005 Jun 28;102(26):9247-52.

28. Wang L, Rothemund D, Curd H, Reeves PR. Species-wide variation in the Escherichia coli flagellin (H-antigen) gene. J Bacteriol. 2003 May;185(9):2936-43. 
bioRxiv preprint doi: https://doi.org/10.1101/2021.11.18.469103; this version posted November 23, 2021. The copyright holder for this preprint (which was not certified by peer review) is the author/funder, who has granted bioRxiv a license to display the preprint in perpetuity. It is made available under aCC-BY 4.0 International license.

29. Hayashi F, Smith KD, Ozinsky A, Hawn TR, Yi EC, Goodlett DR, et al. The innate immune response to bacterial flagellin is mediated by Toll-like receptor 5 . Nature. 2001 Apr 26;410(6832):1099-103.

30. Smith KD, Andersen-Nissen E, Hayashi F, Strobe K, Bergman MA, Barrett SLR, et al. Toll-like receptor 5 recognizes a conserved site on flagellin required for protofilament formation and bacterial motility. Nat Immunol. 2003 Dec;4(12):124753.

31. Samuelsson P, Hang L, Wullt B, Irjala H, Svanborg C. Toll-like receptor 4 expression and cytokine responses in the human urinary tract mucosa. Infect Immun. American Society for Microbiology Journals; 2004 Jun;72(6):3179-86.

32. Ragnarsdottir B, Samuelsson M, Gustafsson MCU, Leijonhufvud I, Karpman D, Svanborg C. Reduced toll-like receptor 4 expression in children with asymptomatic bacteriuria. J Infect Dis. Oxford University Press; 2007 Aug 1;196(3):475-84.

33. Song J, Bishop BL, Li G, Grady R, Stapleton A, Abraham SN. TLR4-mediated expulsion of bacteria from infected bladder epithelial cells. Proc Natl Acad Sci USA. 2009 Sep 1;106(35):14966-71.

34. Tapping RI, Akashi S, Miyake K, Godowski PJ, Tobias PS. Toll-Like Receptor 4, But Not Toll-Like Receptor 2, Is a Signaling Receptor for Escherichia and Salmonella Lipopolysaccharides. The Journal of Immunology. 2000 Nov 15;165(10):5780-7.

35. Wang S, Fleming RT, Westbrook EM, Matsumura P, McKay DB. Structure of the Escherichia coli FlhDC complex, a prokaryotic heteromeric regulator of transcription. Journal of Molecular Biology. 2006 Jan 27;355(4):798-808.

36. Claret L, Hughes C. Rapid Turnover of FlhD and FlhC, the Flagellar Regulon Transcriptional Activator Proteins, during Proteus Swarming. J Bacteriol. 2000 Feb 1;182(3):833-6.

37. Soutourina OA, Bertin PN. Regulation cascade of flagellar expression in Gramnegative bacteria. FEMS Microbiol Rev. 2003 Oct 1;27(4):505-23.

38. Kitagawa R, Takaya A, Yamamoto T. Dual regulatory pathways of flagellar gene expression by ClpXP protease in enterohaemorrhagic Escherichia coli. Microbiology. 2011 Nov 2;157(11):3094-103.

39. Takaya A, Erhardt M, Karata K, Winterberg K, Yamamoto T, Hughes KT. YdiV: a dual function protein that targets FlhDC for ClpXP-dependent degradation by promoting release of DNA-bound FlhDC complex. Mol Microbiol. $2012 \mathrm{Mar}$ 2;83(6):1268-84.

40. Josenhans $\mathrm{C}$, Suerbaum $\mathrm{S}$. The role of motility as a virulence factor in bacteria. Int $\mathrm{J}$ Med Microbiol. 2002 Mar;291(8):605-14.

41. Veening J-W, Smits WK, Kuipers OP. Bistability, epigenetics, and bet-hedging in bacteria. Annu Rev Microbiol. 2008;62:193-210.

42. Mears PJ, Koirala S, Rao CV, Golding I, Chemla YR. Escherichia coli swimming is robust against variations in flagellar number. Elife. 2014;3:e01916. 
bioRxiv preprint doi: https://doi.org/10.1101/2021.11.18.469103; this version posted November 23, 2021. The copyright holder for this preprint (which was not certified by peer review) is the author/funder, who has granted bioRxiv a license to display the preprint in perpetuity. It is made available under aCC-BY 4.0 International license.

43. Brown J, Faulds-Pain A, Aldridge P. The coordination of flagellar gene expression and the flagellar assembly pathway. In: Pili and Flagella: Current Research and Future Trends. 2009. pp. 99-120.

44. Koirala S, Mears P, Sim M, Golding I, Chemla YR, Aldridge PD, et al. A NutrientTunable Bistable Switch Controls Motility in Salmonella enterica Serovar Typhimurium. MBio. 2014;5(5).

45. Jenal U, Stephens $C$. The Caulobacter cell cycle: timing, spatial organization and checkpoints. Curr Opin Microbiol. 2002 Dec 1;5(6):558-63.

46. Alteri CJ, Smith SN, Mobley HLT. Fitness of Escherichia coli during urinary tract infection requires gluconeogenesis and the TCA cycle. PLoS Pathog. 2009 May;5(5):e1000448.

47. Forsyth VS, Armbruster CE, Smith SN, Pirani A, Springman AC, Walters MS, et al. Rapid Growth of Uropathogenic Escherichia coli during Human Urinary Tract Infection. MBio. 2018 Mar 6;9(2).

48. Sintsova A, Frick-Cheng AE, Smith S, Pirani A, Subashchandrabose S, Snitkin ES, et al. Genetically diverse uropathogenic Escherichia coli adopt a common transcriptional program in patients with UTIs. Elife. 2019 Oct 21;8.

49. Wada T, Hatamoto Y, Kutsukake K. Functional and expressional analyses of the anti-FlhD4C2 factor gene ydiV in Escherichia coli. Microbiology. 2012 Jun 1;158(Pt_6):1533-42.

50. Reitzer L, Zimmern P. Rapid Growth and Metabolism of Uropathogenic Escherichia coli in Relation to Urine Composition. Clin Microbiol Rev. 2019 Dec 18;33(1).

51. Spurbeck RR, Alteri CJ, HimpsI SD, Mobley HLT. The Multifunctional Protein, YdiV, Represses $P$ Fimbriae-Mediated Adherence in Uropathogenic Escherichia coli. J Bacteriol. 2013 May 10.

52. Stewart MK, Cookson BT. Non-genetic diversity shapes infectious capacity and host resistance. Trends Microbiol. 2012 Oct;20(10):461-6.

53. Casadesús J, Low DA. Programmed Heterogeneity: Epigenetic Mechanisms in Bacteria. Journal of Biological Chemistry. 2013 May 17;288(20):13929-35.

54. Aldridge $\mathrm{P}$, Jenal U. Cell cycle-dependent degradation of a flagellar motor component requires a novel-type response regulator. Mol Microbiol. 1999 Apr;32(2):379-91.

55. Mowbray CA, Shams S, Chung G, Stanton A, Aldridge P, Suchenko A, et al. High molecular weight hyaluronic acid: a two-pronged protectant against infection of the urogenital tract? Clin Transl Immunol. 2018 Jun 7;7(6):e1021-11.

56. Brzuszkiewicz E, Brüggemann H, Liesegang H, Emmerth $\mathrm{M}$, Olschläger T, Nagy G, et al. How to become a uropathogen: comparative genomic analysis of extraintestinal pathogenic Escherichia coli strains. Proc Natl Acad Sci USA. 2006 Aug 22;103(34):12879-84. 